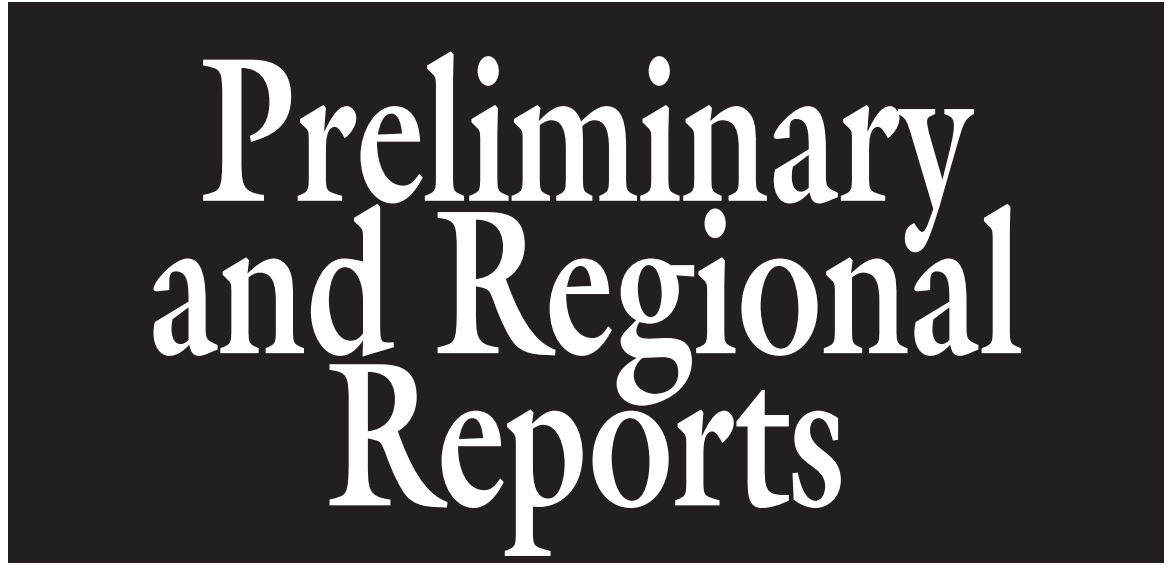

\section{Preplant Sulfur Fertilization Rates and Irrigation Programs on Tomato Growth and Yield}

\author{
Camille E. Esmel ${ }^{1}$, Bielinski M. Santos ${ }^{1,4}$, Eric H. Simonne ${ }^{2}$, \\ Jack E. Rechcigl ${ }^{1}$, and Joseph W. Noling ${ }^{3}$
}

AdDITIONAL INDEX wORDs. Solanum lycopersicum, sulfate, soil fertility, nutrient management, crop nutrition

SUMMARY. A renewed interest in sulfur $(S)$ deficiency has occurred because of reductions in atmospheric depositions of $S$ caused by implementation of clean air regulations around the world. In vegetable production systems, other sources of $S$ exist, such as soil S, fertilizers, and irrigation water. While soil testing and fertilizer labels impart information on quantity of $S$, it is unknown how much $S$ within the irrigation water contributes to the total crop requirement. Two studies were conducted to determine the influence of elemental $S$ fertilization rates and irrigation programs on tomato (Solanum lycopersicum) growth and yield. Irrigation volumes were 3528,5292 , and $7056 \mathrm{gal} /$ acre per day and preplant $S$ rates were $0,25,50$, 100,150 , and $200 \mathrm{lb} /$ acre. Data showed that neither plant height, leaf greenness, soil $\mathrm{pH}$ nor total soil $\mathrm{S}$ content was consistently affected by preplant $\mathrm{S}$ rates. During both seasons, early marketable fruit weight increased sharply when plots were treated with at least $25 \mathrm{lb} /$ acre of preplant $S$ in comparison with the nontreated control. Early fruit weight of extralarge and all marketable grades increased by 1.5 and 1.7 tons/acre, respectively, with the application of $25 \mathrm{lb} /$ acre of $S$. There were no early fruit weight differences, regardless of marketable fruit grade, among preplant $S$ rates from 25 to $200 \mathrm{lb}$ /acre. Based upon this result, adding preplant $S$ to the fertilization programs in sandy soils improves tomato yield and fall within the current recommended application range of $S(30 \mathrm{lb} / \mathrm{acre})$ for vegetables in Florida. At the same time, irrigation volumes did not consistently influence soil $S$ concentration, soil $\mathrm{pH}$, leaf $\mathrm{S}$ concentrations or tomato yield, which suggested that irrigation water with levels of $S$ similar to this location $\left[58 \mathrm{mg} \cdot \mathrm{L}^{-1}\right.$ of sulfate $\left(\mathrm{SO}_{4}\right)$ or $19 \mathrm{mg} \cdot \mathrm{L}^{-1}$ of $\left.\mathrm{S}\right]$ may not meet tomato $\mathrm{S}$ requirement during a short cropping seasons of 12 weeks, possibly because microbes need longer periods of time to oxidize the current $\mathrm{S}$ species in the water to the absorbed $\mathrm{SO}_{4}$ form.

${ }^{1}$ Gulf Coast Research and Education Center, IFAS, University of Florida, 14625 CR 672, Wimauma, FL 33598

${ }^{2}$ Horticultural Sciences Department, IFAS, University of Florida, Gainesville, FL 32611

${ }^{3}$ Citrus Research and Education Center, IFAS, University of Florida, Lake Alfred, FL 33850

${ }^{4}$ Corresponding author. E-mail: bmsantos@ufl.edu.
$S$ deposition in conjunction with increased use of high-analysis fertilizer has caused $S$ deficiencies to become more common in crops (Ceccotti et al., 1998; Scherer, 2001). Other than fertilizer sources, soil and water could act as primary $S$ sources for crop production. It is unclear if either one can meet crop requirements for $S$.

At the plant level, $S$ is indirectly involved in photosynthesis and chlorophyll production (Ahmad and Abdin, 2000), which may be perceived as an increase in greenness in a crop plant. Similarly, improvement in vegetable crop yield and growth occurs when $S$ was included in the fertilizer regime. In potato (Solanum tuberosum), Pavlista (2005) found that an application of $28 \mathrm{~kg} \cdot \mathrm{ha}^{-1} \mathrm{~S}$ improved tuber quality and yield compared with no added S. Rhoads and Olson (2000) found highest yields for cabbage (Brassica oleracea var. capitata) were consistently produced with $22 \mathrm{~kg} \cdot \mathrm{ha}^{-1}$ S. Similarly, Susila (2001) found that tomato and cabbage both responded to the addition of $S$ to the fertilizer regime with rates ranging from 0 to $102 \mathrm{~kg} \cdot \mathrm{ha}^{-1} \mathrm{~S}$. This response occurred regardless of $S$ source and application method (preplant, drip injection, or a combination of both). Both Rhoads and Olson (2000) and Susila (2001) found $S$ sources to be similar and yields were improved across all the studies with $S$ applications within the recommended range for Florida [30 to $40 \mathrm{lb} /$ acre S (Simonne and Hochmuth, 2009)]. None of these studies considered irrigation water $\mathrm{SO}_{4}$ concentrations as an $S$ source for crop production.

Tomato production in Florida often occurs on deep Spodosols (fine sandy soils) with low organic matter $(<2 \%)$, which are inherently low in both organic and inorganic S. Previous studies on tomato have found that some $\mathrm{S}$ sources such as ammonium sulfate $\left[\left(\mathrm{NH}_{4}\right)_{2} \mathrm{SO}_{4}\right]$, ammonium thiosulfate $\left(\mathrm{NH}_{4} \mathrm{~S}_{2} \mathrm{O}_{3}\right)$, ammonium nitrate $\left[\left(\mathrm{NH}_{4} \mathrm{NO}_{3}\right)+\left(\mathrm{NH}_{4}\right)_{2} \mathrm{SO}_{4}\right]$, and potassium sulfate $\left(\mathrm{K}_{2} \mathrm{SO}_{4}\right)$ affected tomato yields similarly (Santos et al., 2007; Susila, 2001). Elemental S is a less expensive $S$ fertilizer source when compared with other $S$ sources that contain nitrogen $(\mathrm{N})$. Elemental $S$ can be an ideal $S$ source for crop growth and yield because it is high in $S$ analysis, insoluble in water, stable in damp and humid conditions, and has to be oxidized to $\mathrm{SO}_{4}-\mathrm{S}$ for plant 
uptake (Solberg et al., 2003). During the process of elemental $S$ fertilizer oxidation by soil microbes, soil $\mathrm{pH}$ is lowered. The rate of elemental S oxidation by soil microbes is dependent upon several factors such as carbon substrate, $\mathrm{N}$ source, soil temperature, and moisture.

The concentration of $S$ in the irrigation water used throughout North America varies widely. Little research is available about the relationship between $S$ content of irrigation water and $S$ requirement in a fertilization program (Olson and Rehm, 1986). Field sites without mineral-bound $S$ sources may have insufficient $S$ dissolved in soil water to move available $S$ to plant roots (Eriksen et al., 1998). Studies on high $\mathrm{SO}_{4}$ irrigation water used water with 175 , 646,862 , and $1743 \mathrm{mg} \cdot \mathrm{L}^{-1} \mathrm{SO}_{4}$ (Drost et al., 1997) and 15.0 and $38.8 \mathrm{~mol} \cdot \mathrm{L}^{-1} \mathrm{SO}_{4}$ (Papadopoulos, 1986) have found mixed results in improving yield of broccoli (B. oleracea var. italica) and tomato. In Florida, $S$ concentrations in drinking water wells can range from 0.07 to $460 \mathrm{mg} \cdot \mathrm{L}^{-1} \mathrm{~S}$ (in the form of $\mathrm{SO}_{4}$ ) with higher concentrations coming from deeper wells (Sacks, 1996). Although these values cover drinking water, the concentration of $S$ within irrigation water drawn from deep wells in Florida is unknown. It has been suggested that water pumped from the Florida aquifer and surface waters may contain appreciable amounts of $S$ for crop production because of the S-like smell commonly associated with hydrogen sulfide volatilization. This often leads to the belief that $S$ in the irrigation water is an $S$ source for crop production (Hochmuth and Hanlon, 2000). Since $S$ concentrations in irrigation water vary widely and current fertilizer practices use high-analysis fertilizer that often lacks $S$, the objectives of this study were to 1 ) investigate the effect of $S$ fertilization rates on tomato growth and yield and 2) assess whether irrigation water could provide the necessary $S$ for tomato production.

\section{Materials and methods}

Two field studies were conducted at the Gulf Coast Research and Education Center (GCREC) in Wimauma, FL, during Spring (March to July) and Fall (August to December) 2008. The soil at the experiment site was Myakka fine sand (sandy siliceous hyperthermic Aeric Alaquods) with a $\mathrm{pH}$ of 6.6 and $1.3 \%$ organic matter. The total $S$ content (both available and unavailable $S$ ) of the soil was $23.5 \mathrm{lb} /$ acre $\mathrm{S}$. Irrigation water from deep wells at GCREC had a $\mathrm{pH}$ of 7.8 and $S$ concentrations were $19 \mathrm{mg} \cdot \mathrm{L}^{-1}$. A standard bedder was used to create raised beds that were $5 \mathrm{ft}$ apart at the center, 8 inches high, 28 inches wide across the top, and 32 inches wide at base. Raised beds were fumigated with $50: 50(\mathrm{v} / \mathrm{v})$ methyl bromide and chloropicrin mixture at $170 \mathrm{lb} /$ acre to eliminate weeds, nematodes, and soil pathogens on $14 \mathrm{Feb}$. and 5 Aug. 2008. Following soil fumigation, two drip tapes $(0.45 \mathrm{gal} / \mathrm{min}$ per $100 \mathrm{ft}$ of bed; T-Systems International, San Diego, CA) were buried 1 inch deep for irrigation and raised beds were covered with metalized polyethylene mulch (Intergro, Clearwater, FL). 'Tygress' tomato seedlings at the four true-leaf stage were transplanted in a single row with 2 -ft spacing between plants on 6 Mar. and 28 Aug. 2008. Tomato plants were staked and tied as described by Csizinszky et al. (2005). All other crop management was conducted according to current recommendations for tomato (Olson et al., 2011).

Treatments were arranged in a split-plot design with six replications, in which the main plots were drip irrigation volumes $(3528,5292$, and $7056 \mathrm{gal} / \mathrm{acre}$ per day) and the subplots were preplant $S$ rates $(0,25,50$, 100,150 , and $200 \mathrm{lb} /$ acre). Irrigation volumes were based upon the historical Penman method for calculating potential evapotranspiration for westcentral Florida (Simonne et al., 2009). Irrigation volumes were adjusted by changing the duration of drip irrigation events: 3528 gal/acre per day was split in three irrigation events of $20 \mathrm{~min}$ each, $5292 \mathrm{gal} /$ acre per day was applied in three irrigation cycles of $30 \mathrm{~min}$ each, and $7056 \mathrm{gal} / \mathrm{acre}$ per day was applied in three irrigations of $40 \mathrm{~min}$ in duration. These irrigation volumes started between 7 and $10 \mathrm{~d}$ after transplanting and were maintained until 12 weeks after transplanting (WAT).

Preplant $S$ rates were applied as two 2 -inch deep bands of elemental $S[90 \% \mathrm{~S}$, prills $2.6 \mathrm{~mm}$ diameter (Tiger 90 CR; Tiger-Sul, Calgary, AB, Canada)] located 12 inches apart on top of raised beds before soil fumigation and plastic mulch application. $\mathrm{N}$ was applied twice weekly using the recommended rates based upon growth stage as described by Olson et al. (2011). The liquid fertilizer contained no additional $S$ and N. Applied phosphorus $(\mathrm{P})$ and potassium $(\mathrm{K})$ were derived from a mix of calcium nitrate, urea ammonium nitrate, phosphoric acid, and potassium nitrate. An $\mathrm{N}$ rate of $200 \mathrm{lb} /$ acre using $6 \mathrm{~N}-0.8 \mathrm{P}-6.6 \mathrm{~K}$ liquid fertilizer was delivered using a standard fertilizer injector (Dosatron, Clearwater, FL). All other nutrients were applied based upon tomato production recommendations and interpretation of preseason soil test results (Olson et al., 2011; Simonne and Hochmuth, 2009).

Soil samples were collected for total soil S at 5 WAT in Spring 2008 and at 4 WAT in Fall 2008. Ten soil cores, which constituted a soil sample, were taken from between tomato plants on the center of raised beds to a depth of 6 inches. Soil samples were air dried and then held at $4.4^{\circ} \mathrm{C}$ until shipment to the laboratory for analysis. Dried 1-lb soil samples were submitted to a commercial analytical laboratory for soil $\mathrm{pH}$ and $\mathrm{S}$ concentration (Waters Agricultural Laboratory, Camilla, GA), which was determined by turbidimetry, as described by the American Society for Testing and

\begin{tabular}{llll}
\hline $\begin{array}{l}\text { Units } \\
\begin{array}{l}\text { To convert U.S. to SI, } \\
\text { multiply by }\end{array}\end{array}$ & U.S. unit & SI unit & $\begin{array}{l}\text { To convert SI to U.S., } \\
\text { multiply by }\end{array}$ \\
\hline 0.3048 & $\mathrm{ft}$ & $\mathrm{m}$ & 3.2808 \\
9.3540 & gal/acre & $\mathrm{L} \cdot \mathrm{ha}^{-1}$ & 0.1069 \\
2.54 & inch $(\mathrm{es})$ & $\mathrm{cm}$ & 0.3937 \\
25.4 & inch $(\mathrm{es})$ & $\mathrm{mm}$ & 0.0394 \\
0.4536 & $\mathrm{lb}$ & $\mathrm{kg}$ & 2.2046 \\
1.1209 & $\mathrm{lb} / \mathrm{acre}$ & $\mathrm{kg} \cdot \mathrm{ha}^{-1}$ & 0.8922 \\
28.3495 & $\mathrm{oz}$ & $\mathrm{g}$ & 0.0353 \\
1 & $\mathrm{ppm}$ & $\mathrm{mg} \cdot \mathrm{L}^{-1}$ & 1 \\
2.2417 & ton $/ \mathrm{acre}$ & $\mathrm{Mg} \cdot \mathrm{ha}^{-1}$ & 0.4461 \\
$\left({ }^{\circ} \mathrm{F}-32\right) \div 1.8$ & ${ }^{\circ} \mathrm{F}$ & ${ }^{\circ} \mathrm{C}$ & $\left(1.8 \times{ }^{\circ} \mathrm{C}\right)+32$ \\
& & &
\end{tabular}


Materials (2006) and the Association of Official Analytical Chemists (2000). Plant tissue samples for $S$ leaf concentrations were collected at 5 WAT in Spring 2008 and at 4 WAT in Fall 2008. Ten most recently matured tomato leaves adjacent to an inflorescence were selected for tissue samples as suggested by Mills and Jones (1996). Dried and ground tissue samples were held at $0{ }^{\circ} \mathrm{C}$ until shipment to the laboratory for analysis. A 2-g subsample of each sample was submitted to a commercial laboratory (Waters Agricultural Laboratory) for total $S$ determination by inductively coupled plasma-optical emission spectrophotometry.

Leaf greenness was collected as an indicator of chlorophyll using a colormeter (SPAD-502; Konica Minolta Sensing, Osaka, Japan) at 6 and 11 WAT in Spring 2008 and at 7 and 11 WAT in Fall 2008. Ten randomly selected recently matured leaves adjacent to an inflorescence were used for leaf greenness assessment. The SPAD-502 colormeter measures absorption in the red $(650 \mathrm{~nm})$ and near-infrared $(940 \mathrm{~nm})$ regions of the spectrum (Ling et al., 2011). The meter uses these two values to calculate a numerical SPAD value, which is proportional to the amount of chlorophyll (Blunden et al., 1997). Typical SPAD values are between 0 and 50 with a range of 0 to 80 , with $0=$ white and $80=$ dark green (Ling et al., 2011; Santos, 2010). Plant height was collected at 5 and 13 WAT in Spring 2008, whereas in Fall 2008, plant height was collected at 5 WAT.

Following local practices, tomato fruit were harvested twice during 12 and 13 WAT in Spring 2008 and 11 and 14 WAT in Fall 2008, and they were graded according to the current standards for size categories (Brown, 2011). Sizes were extralarge (2-25/ 32 inches in diameter), large (2-29/ 32 to $2-17 / 32$ inches), medium (2$19 / 32$ to $1-9 / 32$ inches), and cull $(<2-5 / 16$ inches). Marketable tomato fruit weight was calculated as the sum of medium, large, and extralarge yield for both harvests, while early tomato fruit weight included only the first harvest of each season. All collected measurements were subjected to an analysis of variance to determine single-factor and interactions significance $(P<0.05)$ using a general linear model, as well as the effects of linear contrasts through regression analysis
(SAS version 9.2; SAS Institute, Cary, NC).

\section{Results and discussion}

There were significant season by treatment interactions for most of the variables under study with the exception of early and total fruit weight. Therefore, most data were analyzed separately. The irrigation volume by

Table 1. Effects of irrigation volume and preplant sulfur (S) rates on tomato leaf greenness at Wimauma, FL, in Spring and Fall 2008.

\begin{tabular}{|c|c|c|c|c|}
\hline \multirow{4}{*}{$\begin{array}{l}\text { Irrigation volume } \\
\left(_{\text {gal/acre per day })^{z}}\right.\end{array}$} & \multicolumn{4}{|c|}{ Leaf greenness } \\
\hline & \multicolumn{2}{|c|}{ Spring 2008} & \multicolumn{2}{|c|}{ Fall 2008} \\
\hline & $6 \mathrm{WAT}^{\mathrm{y}}$ & 11 WAT & 7 WAT & $11 \mathrm{WAT}$ \\
\hline & \multicolumn{4}{|c|}{$[S P A D \text { value }(0-80 \text { scale })]^{x}$} \\
\hline 3528 & 48 & 48 & 45 & 48 \\
\hline 5292 & 47 & 44 & 44 & 43 \\
\hline 7056 & 46 & 43 & 44 & 44 \\
\hline$P<0.05$ & NS & * & NS & NS \\
\hline Linear contrasts (irrigation volume) & NS & * & NS & NS \\
\hline \multicolumn{5}{|l|}{ Preplant $S$ rates $(1 \mathrm{~b} / \text { acre })^{\mathrm{z}}$} \\
\hline 0 & 48 & 45 & 46 & 45 \\
\hline 25 & 48 & 46 & 45 & 48 \\
\hline 50 & 46 & 44 & 44 & 45 \\
\hline 100 & 48 & 45 & 42 & 46 \\
\hline 150 & 47 & 47 & 44 & 44 \\
\hline 200 & 47 & 46 & 46 & 42 \\
\hline$P<0.05$ & NS & NS & NS & * \\
\hline Linear contrasts (preplant $S$ rates) & NS & NS & NS & * \\
\hline
\end{tabular}

Table 2. Effects of irrigation volume and preplant sulfur (S) rates on soil $\mathrm{pH}$ and total S content at Wimauma, FL, in Spring and Fall 2008.

\begin{tabular}{|c|c|c|c|c|c|c|}
\hline \multirow{3}{*}{$\begin{array}{l}\text { Irrigation volume } \\
\left(_{\text {gal/acre per day })^{z}}\right.\end{array}$} & \multicolumn{4}{|c|}{ Soil pH } & \multicolumn{2}{|c|}{ Total soil S $(\mathrm{lb} / \mathrm{acre})^{\mathrm{z}}$} \\
\hline & \multicolumn{2}{|c|}{ Spring 2008} & \multicolumn{2}{|c|}{ Fall 2008} & \multirow{2}{*}{$\frac{\text { Spring } 2008}{5 \text { WAT }}$} & \multirow{2}{*}{$\begin{array}{c}\text { Fall } 2008 \\
4 \mathrm{WAT} \\
\end{array}$} \\
\hline & 5 WAT $^{\mathrm{y}}$ & 13 WAT & 4 WAT & $15 \mathrm{WAT}$ & & \\
\hline 3528 & 6.7 & 6.3 & 6.8 & 6.7 & 22.4 & 31.9 \\
\hline 5292 & 6.6 & 6.3 & 6.7 & 6.7 & 22.8 & 33.1 \\
\hline 7056 & 6.6 & 6.1 & 6.7 & 6.8 & 21.9 & 30.0 \\
\hline$P<0.05$ & NS & NS & NS & NS & NS & NS \\
\hline $\begin{array}{l}\text { Linear contrasts } \\
\text { (irrigation) }\end{array}$ & NS & NS & NS & NS & NS & NS \\
\hline \multicolumn{7}{|l|}{$\begin{array}{l}\text { Preplant } S \text { rates } \\
\quad(1 \mathrm{~b} / \mathrm{acre})^{\mathrm{z}}\end{array}$} \\
\hline 0 & 6.7 & 6.8 & 6.7 & 6.7 & 20.1 & 29.6 \\
\hline 25 & 6.6 & 6.6 & 6.7 & 6.8 & 23.0 & 32.1 \\
\hline 50 & 6.6 & 6.2 & 6.7 & 6.7 & 20.4 & 29.9 \\
\hline 100 & 6.6 & 6.2 & 6.7 & 6.8 & 20.3 & 31.0 \\
\hline 150 & 6.6 & 6.0 & 6.8 & 6.8 & 24.3 & 31.4 \\
\hline 200 & 6.6 & 5.8 & 6.8 & 6.8 & 26.3 & 34.8 \\
\hline$P<0.05$ & NS & * & NS & NS & NS & NS \\
\hline $\begin{array}{l}\text { Linear contrasts } \\
\text { (preplant S rates) }\end{array}$ & NS & * & NS & NS & NS & NS \\
\hline
\end{tabular}

elemental S rate interaction was not significant for any of the variables during both seasons. Plant height was not influenced by either factor or their interaction (data not presented). Leaf greenness was marginally influenced by either factor, and it changed only late into both seasons (11 WAT) when most fruit are during the fast-filling and maturing stage. During late Spring 
2008, leaf greenness declined with increased irrigation volumes, while in Fall 2008, the same occurred only when preplant $S$ rates incremented (Table 1). These results are somewhat similar to those shown by Barbieri et al. (2009) in which $S$ nutrition did not have an effect on leaf greenness of turnip (Brassica rapa).

The vast majority of total soil $S$ measurements and soil $\mathrm{pH}$ were not influenced by either irrigation volumes or applied preplant $S$ rates during both seasons (Table 2). However, preplant $S$ rates affected the end-ofseason $\mathrm{pH}$ values in Spring 2008, decreasing linearly as preplant $S$ rates increased, which is expected from the application of elemental $S$ in the soil. The fact that the nontreated control plots ( $0 \mathrm{lb} /$ acre of $S$ ) had the same total soil $S$ than the other $S$-treated plots at 4 or 5 WAT confirmed that this measurement is not an appropriate indicator of available $S$ in the soil. Seasonal temperature differences between cropping seasons may have played a significant role in soil $\mathrm{pH}$ differences. For instance, spring tomato production season in Florida tends to start cool in late February and early March (minimum $38^{\circ} \mathrm{F}$, maximum $86^{\circ} \mathrm{F}$ ) and end hot in June (minimum $66^{\circ} \mathrm{F}$, maximum $97^{\circ} \mathrm{F}$ ), whereas fall tomato production season between August and December is the reverse. Solberg et al. (2003) suggested that elemental $S$ fertilizers require oxidation time to become plant-available $\mathrm{SO}_{4}-\mathrm{S}$, which may help explain the lack of differences in applied elemental $S$. The oxidation of the applied preplant $S$ rates might need longer than 12 weeks, which is the average tomato production season in Florida, to become fully oxidized by soil microbes in Florida sandy soils.

Irrigation volumes influenced $S$ leaf concentrations in Fall 2008, but not in the previous season (Table 3 ). Foliar $S$ values ranged between $0.55 \%$ and $0.66 \% \mathrm{~S}$, which are within the sufficiency levels for tomato (Olson et al., 2011; Susila, 2001). One possible explanation for the lack of significance of $S$ rates at 4 and 5 WAT on leaf $S$ concentration could be that the measurements were taken too early into the seasons and the beneficial effect of the nutrient is slowly accumulated over time in the plant. Early yield of extralarge and marketable fruit were influenced by preplant $S$ rates each season in the combined analysis of both seasons (Fig. 1). However, there was no significant effect of the factor and their interactions on the total fruit weight (extralarge and all marketable categories) during both combined seasons (Table 3 ), averaging between 13.6 and 15.2 tons/acre across preplant $S$ rates, which is within the range of yield produced by Florida growers. During both seasons, early marketable fruit weight increased sharply when plots were treated with at least $25 \mathrm{lb} /$ acre of preplant $S$ in comparison with the

Table 3. Effects of irrigation volume and preplant sulfur $(S)$ rates on $S$ concentration in tomato leaves and total fruit weight at Wimauma, FL, in Spring and Fall 2008.

\begin{tabular}{|c|c|c|c|c|}
\hline \multirow{3}{*}{$\begin{array}{l}\text { Irrigation volume } \\
{\text { (gal/acre per day })^{z}}\end{array}$} & \multicolumn{2}{|c|}{$S$ leaf concn $(\%)$} & \multirow{2}{*}{\multicolumn{2}{|c|}{$\begin{array}{c}\text { Total fruit wt (tons/acre) } \\
\text { Spring and Fall } 2008\end{array}$}} \\
\hline & \multirow{2}{*}{$\frac{\text { Spring } 2008}{5 \text { WAT }^{\mathrm{y}}}$} & \multirow{2}{*}{$\begin{array}{c}\text { Fall } 2008 \\
4 \text { WAT } \\
\end{array}$} & & \\
\hline & & & Extralarge & Marketable \\
\hline 3528 & 0.55 & 0.61 & 9.9 & 15.5 \\
\hline 5292 & 0.57 & 0.66 & 9.1 & 14.5 \\
\hline 7056 & 0.57 & 0.59 & 8.7 & 14.0 \\
\hline$P<0.05$ & NS & $*$ & NS & NS \\
\hline $\begin{array}{c}\text { Linear contrast } \\
\text { (irrigation) }\end{array}$ & NS & * & NS & NS \\
\hline \multicolumn{5}{|l|}{$\begin{array}{l}\text { Preplant } S \text { rates } \\
\qquad(\mathrm{lb} / \mathrm{acre})^{\mathrm{z}}\end{array}$} \\
\hline 0 & 0.55 & 0.64 & 8.3 & 13.6 \\
\hline 25 & 0.56 & 0.60 & 9.2 & 14.4 \\
\hline 50 & 0.56 & 0.61 & 9.6 & 14.9 \\
\hline 100 & 0.57 & 0.63 & 9.6 & 15.2 \\
\hline 150 & 0.56 & 0.63 & 9.7 & 15.0 \\
\hline 200 & 0.57 & 0.62 & 9.2 & 15.0 \\
\hline$P<0.05$ & NS & NS & NS & NS \\
\hline $\begin{array}{l}\text { Linear contrasts } \\
\quad \text { (preplant } S \text { rates })\end{array}$ & NS & NS & NS & NS \\
\hline
\end{tabular}

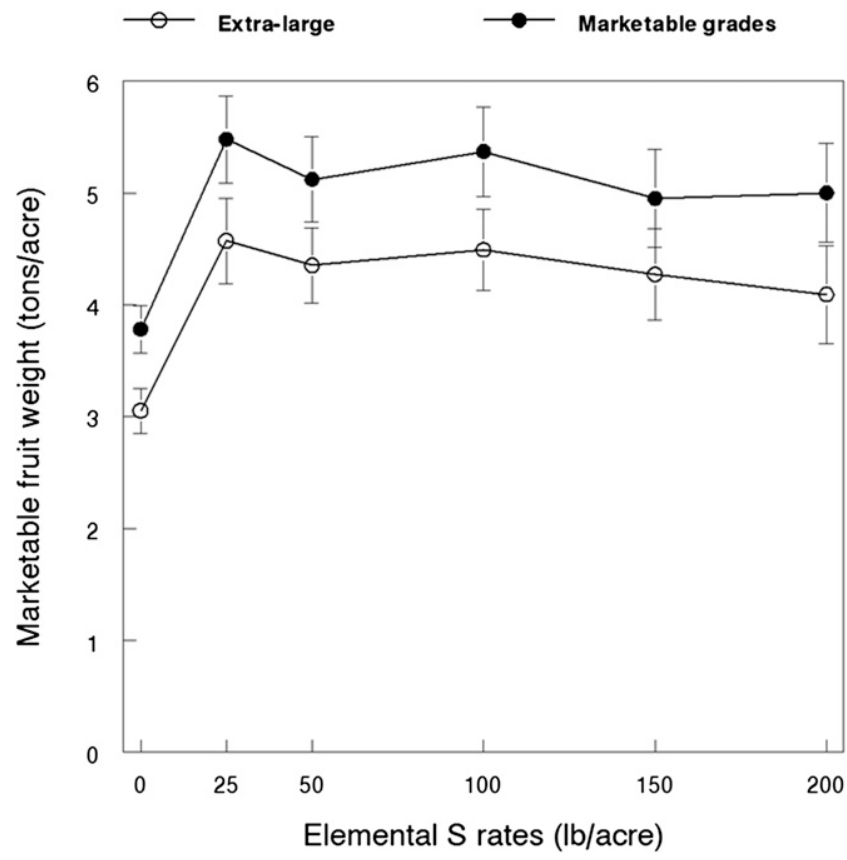

Fig. 1. Effects of preplant sulfur (S) rates on early tomato marketable fruit weight of extralarge and all marketable grades. Treatment mean values separated with SE bars; $1 \mathrm{lb} / \mathrm{acre}=1.1209 \mathrm{~kg} \cdot \mathrm{ha}^{-1}, \mathrm{l}$ ton $/$ acre $=2.2417 \mathrm{Mg} \cdot \mathrm{ha}^{-1}$. 
nontreated control. Early fruit weight of extralarge and all marketable grades increased by 1.5 and 1.7 tons/acre, respectively, with the application of $25 \mathrm{lb} /$ acre of S (Fig. 1). There were no early fruit weight differences, regardless of marketable fruit grade, among preplant $S$ rates from 25 to $200 \mathrm{lb} /$ acre. Based upon this result, adding preplant $S$ to the fertilization programs in sandy soils improves tomato yield and fall within the current recommended application range of $S(30 \mathrm{lb} /$ acre $)$ for vegetables in Florida (Simonne et al., 2009). These results agree with those presented by Susila (2001), who showed that $S$ fertilization could increase tomato yields. At the same time, irrigation volumes did not consistently influence soil $S$ concentration, soil $\mathrm{pH}$, leaf $\mathrm{S}$ concentrations, or tomato yield, which suggested that irrigation water with concentrations of $S$ similar to this location $\left(58 \mathrm{mg} \cdot \mathrm{L}^{-1}\right.$ of $\mathrm{SO}_{4}$ or $19 \mathrm{mg} \cdot \mathrm{L}^{-1}$ of S) may not meet tomato $S$ requirement during a short cropping seasons of 12 weeks, especially after soil fumigation that might have reduced the microbial conversion rate. It is possible that the form of $S$ present within the irrigation water in Florida needs to be oxidized by microbes to form $\mathrm{SO}_{4}$, which is the $\mathrm{S}$ form absorbed by most crops. While tomato leaf $S$ concentrations stayed within the recommended ranges for $S$, early yield was increased with the addition of elemental $S$ to the fertilizer regime. Based upon these results, the current recommended rate of $30 \mathrm{lb} /$ acre of $S$ should be incorporated into the fertilizer regime to maximize early yield of fresh market tomato.

\section{Literature cited}

Ahmad, A. and M.Z. Abdin. 2000. Photosynthesis and its related physiological variables in the leaves of Brassica genotypes as influenced by sulphur fertilization. Physiol. Plant. 110:144-149.

American Society for Testing and Materials. 2006. ASTM D 516-02: Standard test method for sulfate ion in water. In: Annual book of ASTM standards. Vol. 19, Section 5. ASTM Intl., West Conshohocken, PA.

Association of Official Analytical Chemists. 2000. Chapter 11-Water and salt: AOAC Official Method 973.57 Sulfate in water. Turbidimetric method, p. 23. In: W. Horwitz (ed.). Official methods of analysis. Assn. Offic. Anal. Chemists, Arlington, VA.

Barbieri, G., A. Bottino, F. Orsini, and S. De Pascale. 2009. Sulfur fertilization and light exposure during storage are critical determinants of the nutritional value of ready-to-eat friariello campano (Brassica rapa L. subsp. sylvestris). J. Sci. Food Agr. 89:2261-2266.

Blunden, G., T. Jenkins, and Y. Liu. 1997. Enhanced leaf chlorophyll levels in plants treated with seaweed extract. J. Appl. Phycol. 8:535-543.

Brown, R.L. 2011. Florida Tomato Committee: Regulatory Bulletin No.1.20 Nov. 2011. <http://www.floridatomatoes. org/Regulations/Domestic-Markets.aspx>.

Ceccotti, S.P., R.J. Morris, and D.L. Messick. 1998. A global overview of the sulphur situation: Industry's background, market trends, and commercial aspects of sulphur fertilizers. p. 175-202. In: E. Schnug (ed.). Sulphur in agroecosystems. Kluwer Academic Publishers, Norwell, MA.

Csizinszky, A.A., D.J. Schuster, J.B. Jones, and J.C. van Lenteren. 2005. Crop production, p. 237-256. In: E. Heuvelink (ed.) Tomatoes. CABI Publishing, Cambridge, MA.

Drost, D.T., J.W. MacAdam, L.M. Dudley, and N. Soltani. 1997. Response of bean and broccoli to high-sulfate irrigation water. HortTechnology 7:429-434.

Eriksen, J., M.D. Murphy, and E. Schnug. 1998. The soil sulphur cycle, p. 39-73. In: Schnug (ed.). Sulphur in agroecosystems. Kluwer Academic Publishers, Norwell, MA.

Hochmuth, G.J. and A.E. Hanlon. 2000. Commercial vegetable fertilization principles. 20 Nov. 2011. <http://edis.ifas.ufl. edu/pdffiles/CV/CV00900.pdf>.

Ling, Q., W. Huang, and P. Jarvis. 2011. Use of a SPAD-502 meter to measure leaf chlorophyll concentration in Arabidopsis thaliana. Photosyn. Res. 107:209-214.

Mills, H.A. and J.B. Jones. 1996. Plant analysis handbook II. MicroMacro Publishing, Athens, GA.

Olson, R.A. and G.W. Rehm. 1986. Sulfur in precipitation and irrigation waters and its effects on soils and plants, p. 279-293. In: M.A. Tabatabai. (ed.). Sulfur in agriculture. Amer. Soc. Agron., Crop Sci. Soc. Amer., Soil Sci. Soc. Amer., Madison, WI.

Olson, S.M., W.M. Stall, G.E. Vallad, S.E. Webb, S.A. Smith, E.H. Simonne, E. McAvoy, B.M. Santos, and M. OzoresHampton. 2011. Tomato production in
Florida, p. 309-332. In: S.M. Olson and B.M. Santos (eds.). Vegetable production handbook for Florida, 2010-2011. Vance Publishing, Lenexa, KS.

Papadopoulos, I. 1986. Effect of high sulfate irrigation waters on soil salinity and yields. Agron. J. 78:429-432.

Pavlista, A. 2005. Early-season application of sulfur fertilizer increases potato yield and reduce defects. Agron. J. 97:599-603.

Rhoads, F.M. and S.M. Olson. 2000. Cabbage response to sulfur source and nitrogen rate. Proc. Soil Crop Sci. Soc. Fla. 60:37-40.

Sacks, L.A. 1996. Geochemical and isotopic composition of ground water with emphasis on sources of sulfate in the upper Floridian aquifer in parts of Marion, Sumter, and Citrus counties, Florida. Water-Resources Investigations Rpt. 95-4251. 20 Nov. 2011. <http://fl.water. usgs.gov/publications/Abstracts/wri95_ 4251_sacks.html>.

Santos, B.M. 2010. Effect of preplant nitrogen and sulfur fertilizer sources on strawberry. HortTechnology 20:193-196.

Santos, B.M., C.E. Esmel, J.E. Rechcigl, and H. Moratinos. 2007. Effects of sulfur fertilization on tomato production. Proc. Florida State Hort. Soc. 120:189-190.

Scherer, H.W. 2001. Sulphur in crop production-invited paper. Eur. J. Agron. 14:81-111.

Simonne, E.H. and G.J. Hochmuth. 2009. Soil and fertilizer management for vegetable production in Florida, p. 3-15. In: S.M. Olson and E.H. Simonne (eds.). Vegetable production handbook for Florida. Vance Publishing, Lenexa, KS.

Simonne, E.H., M.D. Dukes, and D.Z. Haman. 2009. Principles and practices of irrigation management for vegetables, p. 33-39. In: S.M. Olson and E.H. Simonne (eds.). Vegetable production handbook for Florida. Vance Publishing, Lenexa, KS.

Solberg, E.D., S.S. Malhi, M. Nyborg, and K.S. Gill. 2003. Fertilizer type, tillage, and application time effects on recovery of $\mathrm{SO}_{4}-\mathrm{S}$ from elemental sulfur fertilizers in fallow field soils. Commun. Soil Sci. Plant Anal. 34:815-830.

Susila, A.D. 2001. Sulfur nutrition requirement for drip irrigated tomato, pepper and cabbage. Univ. Florida, Gainesville, PhD Diss.

Tabatabai, M.A. 1984. Importance of sulphur in crop production. Biogeochemistry $1: 45-62$. 